\title{
Country risk endogeneity, capital flows and capital controls in Brazil
}

\author{
Endogeneidade de risco país, fluxos de capital \\ e controles de capital no Brasil
}

FLÁVIO VIEIRA*

MÁRCIO HOLLAND******

RESUMO: O principal objetivo do artigo é analisar a relação entre fluxos de capital, risco país, controles de capital e diferencial de taxas de juros no Brasil desde meados dos anos 90 . Sabemos quão polêmico é o papel e a eficácia dos controles de capital durante os episódios de crises, e como os países emergentes podem ficar presos em um círculo vicioso expresso através do comportamento de duas variáveis cruciais: o risco-país e a taxa de juros. Os resultados empíricos sugerem que o diferencial de taxa de juros é endógeno ao risco país, explicado principalmente quando consideramos a existência de uma probabilidade de inadimplência no contexto de uma alta dívida pública.

PALAVRAS-CHAVE: Fluxos de capitais; risco-país; controles de capitais.

ABSTRACT: The main goal of the paper is to analyze the relationship between capital flows, country risk, capital controls and interest rate differential in Brazil since the mid of 90s. We know how controversial is the role and the effectiveness of capital controls during episodes of crises, and how emerging countries can be trapped in a vicious circle expressed through the behavior of two crucial variables: the country risk and the interest rate. Empirical results suggest that interest rate differential is endogenous to country risk, mainly explained when we consider the existence of a probability of default in the context of a high public debt. KEYWORDS: Capital flows; country-risk; capital control.

JEL Classification: F30; E43; E44.

\footnotetext{
* Professor of Economics, Universidade Federal de Uberlândia -UFU, Uberlândia/MG, Brasil. E-mail: flaviovieira@ufu.br.

* * Professor of Economics, Universidade Federal de Uberlândia - UFU, Uberlândia/MG, Brasil; CNPq Researcher. E-mail: mholland@ufu.br.

$* *$ We are thankful to comments from Otaviano Canuto (FEA/USP). All remaining errors are ours.
} 


\section{INTRODUCTION}

The present paper intends to analyze the relationships between capital flows, country risk, capital controls and interest rate differential in Brazil since mid 90s. It is important to emphasize that the paper provides an interesting approach that allows one to understand how emerging countries can be trapped in a vicious circle expressed by movements in the country risk and interest rate variables. We are concerned to examine the probability of default that can arise due to a perverse dynamic of this relationship, especially when the country faces a substantial increase in the amount of interest paid in the short-run.

We can anticipate that there are some evidence supporting the hypothesis of the endogeneity of the country risk in Brazil, mainly after 1999, and the amount of the interest paid due the public debt and its composition is the main transmission channel between the interest rate and the probability of the default

The paper is divided in three sections. In the next section we develop a survey of the literature focusing on theoretical and policy issues related to capital controls and capital flows, mainly highlighting the effectiveness and limitations of capital controls during episodes of financial crises for emerging economies, and the evolving role played by capital flows in such economies since early 90 s. Section two develops in a short way the arguments to understand the main issues related to the recent debate over the causality and the dynamics of country risk and interest rate in Brazil. Section three deals with the modeling framework adopted and the empirical results for Brazil from July of 1994 to April of 2002, using monthly time series. Last section draws some concluding remarks

\section{A SURVEY OF CAPITAL CONTROLS IN EMERGING MARKETS}

It is fair to say that globalization of capital markets has been beneficial when we consider the argument that it allows capital flows to move towards its most attractive destination but at the same time this process has been associated with episodes of dramatic financial crises. In this scenario, there is an instigating debate regarding the role of international capital flows in triggering such crises, and if that is the case, capital controls become an important policy tool to be used by emerging countries as it happened quite often during the 90 s.

Recently, a number of studies have argued that free capital mobility has created a highly unstable international financial system and developing countries need to manage capital flows. It is important to say that this idea is not a new one and it goes way back to James Tobin (1978) who argued that in order to reduce macroeconomic instability would require the adoption of a global tax on foreign exchange transactions to reduce speculation in international financial markets.

The rationale for imposing restrictions (capital controls) on international capital flows can be associated with the belief that capital markets are usually characterized by market failures and distortions (information asymmetry), and such 
imperfections are magnified by difficulties in enforcing contracts across borders and by a kind of herb behavior when investors may overreact to external shocks.

One of the reasons most often voiced in the defense of using capital controls during periods of crises is associated with the idea that it allows the central bank stem the drain on foreign exchange reserves, and the monetary authorities could initially raise interest rates and once capital controls are in place, it gives room for a lower and more stable interest rate, which acts in a pro-cycle way. It is also important to notice that capital controls introduce a wedge between domestic and foreign interest rates, and the domestic interest rate policy does not need to follow international interest rates when facing the consequences of an international crises and the break down of uncovered interest parity.

The discussion of some policy issues regarding the effectiveness of imposing capital controls should be carried out with the understanding of the required steps (sequencing reform) towards the liberalization of the capital account. The main issue is not on whether capital controls should be eliminated or not, but under which conditions (when and how fast) they would be effective in achieving desirable economic outcomes. Most country experiences with capital controls have shown that the private sector found ways of getting around capital controls, usually adopting strategies based on overinvoicing (underinvoicing) imports (exports) and mislabeling the nature of capital movements (short-term portfolio flows labeled as trade credit).

The majority of the studies have argued that prior to liberalizing the capital accounts it is necessary to reverse major fiscal imbalances and achieve macroeconomic stability. The past recent experience of many developing countries, including Brazil since mid 90s, has shown that price stability was obtained but still remains to implement fiscal reforms to improve the overall macroeconomic fundaments of the economy. Other than this, it has been pointed out that establishing a sound banking system is also necessary before developing countries can lift restrictions on capital mobility since banks will intermediate the inflows of capital, which should not happen in an inefficient way.

The literature on capital controls has grown fast in the aftermath of different crises during the $90 \mathrm{~s}$, affecting in many ways developing countries. A number of authors have argued that capital mobility plays a destabilizing role, and that emerging economies would benefit by imposing restrictions on capital flows. One important issue addressed by the literature is how to measure capital controls. Some indexes have been constructed but each one of them has some limitation. Alesina, Grilli and Milesi-Ferreti (1994) constructed a dummy variable index of capital account liberalization, while Rodrik (1998) developed a similar index to investigate the effects of capital controls on growth, inflation and investment. ${ }^{1}$

The work by Reinhart and Smith (2001) examines the role of temporary con-

\footnotetext{
${ }^{1}$ The construction of such indexes on capital controls uses data from the IMF's Exchange Rate and Monetary Arrangements publication. We have constructed an index of capital controls following the methodology adopted by Cardoso and Goldjfan (1998).
} 
trols on capital inflows, emphasizing that capital controls have two crucial features: they are asymmetric (the target is on capital inflows and not to capital outflows) and temporary. The authors examine possible reasons for policymakers to adopt controls on capital inflows and two types of shocks that can result in excessive capital inflows (temporary changes in the foreign interest rate and in domestic monetary policy). The major empirical findings are that the tax rate on capital inflows should be very high to affect the capital account balance, the economic benefit of taxing capital inflows are not significant, and the existence of procrastination in the removal of capital controls (can reverse welfare benefits).

Malaysia and Thailand are two emerging countries making use of capital controls during episodes of financial crises in the recent past, where Edison and Reinhart (2000) examines their experience. The main empirical findings suggest that capital controls help reducing interest rate volatility but there is mixed evidence for exchange rate volatility. Another important result refers to a wider and more variable bidask spread during control periods, and little evidence that capital controls were effective in reducing volatility spillovers.

Kaminsky and Schmukler (2000) deals with the question of whether or not capital controls affects the link between domestic and foreign stock market prices and interest rates, in other words, if it matters for international market integration. The authors find little evidence that capital controls can segment domestic and foreign markets, and even when they do, the effects do not last long. Finally, they find that it is difficult to distinguish the effects of controls on inflows and outflows.

The Chilean experience during the 90s has been examined in details by De Gregorio, Edwards and Valdes (2000) who develops a work where they address the issue of whether or not controls on capital inflows are efficient through the use of unremunerated reserve requirement and the effects on interest rates, the volume and composition of capital inflows and the real exchange rate. The main empirical findings suggests that it is difficult to find long-run effects, and capital controls generate an increase in the interest rate differential only in the short-run, no effects on the real exchange rate, and a significant effect in the composition of capital inflows in favor of a longer maturity.

Another study linked to Chile's experience with controls on inflows and outflows of capital during the 90s was developed by Edwards (1999) and the empirical results suggest that controls on outflows are not effective while controls on inflows has the advantage of affecting the maturity of foreign debt, which is a desirable outcome for the monetary authorities. The three main goals of Chile's capital controls were to slow down the inflow of capital and change its composition towards capital of longer maturities; to reduce and postpone real exchange rate appreciation; and to help the monetary authorities to adopt an independent monetary policy (maintaining interest rate differential). The author also found that controls on capital inflows are not sufficient to eliminate financial instability. The GARCH estimation reveals that the restrictions on capital inflows were successful in reducing stock market instability, but not for short-run interest rate volatility.

Montiel and Reinhart (1999) using a new data to discuss the effects of restric- 
tions on capital inflows found evidence that controls are important to explain changes in the composition of capital flows in the direction intended (reducing the share of short-term and portfolio flows, and increasing foreign direct investment). The authors address the issue of whether external (international interest rates) or internal (structural reforms) factors are more important to explain the increase in the financial flows to emerging economies, and relate this with the question of how these countries respond to an increase in capital flows. ${ }^{2}$ The empirical evidence indicates that capital inflow is more volatile in Latin America than in Asia, and short-term capital is more volatile than all other types of capital flows. The adoption of sterilized intervention increases the volume of total capital flows through short-term capital, and capital controls have no significant effect on reducing the overall volume of flows but they affect the composition of capital flows in favor of foreign direct investments. Finally, short-term flows are not sensitive to changes in international interest rates, while the composition of capital flows does respond to such changes.

Cardoso and Goldfajn (1998) develops an index of capital controls to examine the main determinants of capital flows to Brazil, taking into account possible endogeneity of capital controls. One of the results they found was that capital account restrictions have some impact on domestic interest rates and that government has an active role by changing capital controls when facing changes in capital flows. Capital controls have a temporary effect in the composition of capital flows but no long-term effect. The authors found that the causality runs in both directions, capital controls affects capital flows and reacts to changes in capital flows.

Another study of capital controls in Brazil is the one developed by Garcia and Valpassos (1998) suggesting that capital controls were ineffective for Brazil in preventing inflows of short-term foreign capital to invest in public debt assets, but they had a temporary effect. Interest rate differential has been the main determinant of short-term capital inflows to Brazil since early 1990s, and the composition of capital flows has moved away from short-term and portfolio flows and towards FDI through the last decade and especially after the Real Plan in July 1994.

One of the main conclusion we can draw after analyzing the empirical evidence on capital controls in emerging countries is that a long-run solution to the problem of a high vulnerability to international capital flows requires the adoption of a more flexible exchange rate regime, a better banking supervisory system, and the implementation of structural reforms (correction of fiscal imbalances is a crucial example), but even when countries have moved in the right direction it does not mean that they are insulated from international financial shocks. Once we have developed the literature review and the policy issues related to capital controls and interest rate differential we came up with the conclusion that there is a missing variable,

\footnotetext{
${ }^{2}$ The authors discuss the influence of Pull (improvements in the risk-return of assets) and Push (reduce in the attractiveness of lending to industrial country borrowers) factors.
} 
the role of the country risk, when trying to understand the effectiveness of capital controls in emerging markets. Our main contribution will be to include such variable into the analysis of the Brazilian experience since the mid of the 90s.

\section{COUNTRY RISK AND INTEREST RATE IN BRAZIL: A DEBATE OVER THE RECENT EXPERIENCE}

Brazil has recently experienced some economic problems associated to a period of financial crisis and contagion from unfavorable external shocks in the turn of the new century, bringing up a debate over the relationship between country risk, interest rate and the exchange rate. In this environment, some policy proposals gain a lot of attention in the political and academic scenario, especially the one formulated by Bresser-Pereira and Nakano (2002). The authors suggest that in order to reduce the public debt sector deficit and increase economic growth it is necessary to follow a domestic monetary policy based on lower interest rates. Other than this, the proposal also argues that government should allow the exchange rate to depreciate, which will contribute to reduce the current account deficit. ${ }^{3}$

The logic associated with this policy proposal suggesting the crucial role of a reduction in the interest rate and real exchange rate depreciation in a flexible exchange rate system is based on the argument that the main cause of high real interest rates is not a high country risk but the causality is the reverse. ${ }^{4}$ Bresser-Pereira and Nakano (2002) argue that when the Central Bank sets a high interest rate, the outcome is an increase in the debt/GDP ratio over time and a higher country risk.

A different approach regarding the policy proposal described above is suggested by Pastore (2002). The author argues that the observance of a high country risk than what is suggested by the macroeconomic fundaments of the economy has been mostly independent of monetary policy actions, and so, they are not strictly related to the interest rate level. Country risk is influenced by external shocks and by an incomplete fiscal adjustment according to Pastore (2002), and this argument imposes some restrictions to the original proposal by Bresser-Pereira and Nakano. Pastore (2002) argues that it can be possible but not desirable to rely on the devaluation of the real exchange rate in order to adjust the current account deficit because it is necessary to have a tighter fiscal policy to reduce the aggregate level of absorption.

It is also important to notice that for a country like Brazil that is heavily de-

\footnotetext{
${ }^{3}$ It should be mentioned that a depreciation of the nominal exchange rate together with a stable domestic inflation rate should result in a real exchange rate depreciation assuming that foreign prices follow a relatively stable path. Our focus of attention in this paper is not the exchange rate path but the relationcausality between country risk and interest rate when analyzing capital flows and capital controls.

${ }^{4}$ The empirical answer to this question is reported in the next section after using the variance decomposition and the Granger causality test.
} 
pendent on capital inflows, any external shock is generally associated with some kind of an upward pressure in the exchange rate, which increases the debt/GDP ratio and affects in a negative way the perception of the public sector solvency, and so the country risk. Therefore, one should expect the country risk variable to have a more volatile behavior during periods of financial crises and / or external shocks and once those periods are passed the country risk level will be closely related to the macroeconomic fundamentals.

\section{MODEL SPECIFICATION AND EMPIRICAL RESULTS FOR BRAZIL}

The empirical analysis uses a time series analysis based on monthly data from July of 1994 to April of 2002 where this sample includes two different exchange rate regimes, one that is more fixed (up to January 1999), and the second one considered as a dirty float regime. Each time series was obtained from the Central Bank of Brazil. One of the tasks of this paper is to investigate the relationship between interest rate, country risk and capital flows in Brazil during the recent period.

More recently, the role of capital flows has been questioned in different ways, especially in countries like Brazil that has undergone liquidity shocks for quite a long time, and the monetary authorities has kept the interest rate at a high level. At the same time, this period is associated with a more volatile country risk facing persistently upward movements.

In order to measure capital control, we examined the Brazilian legislation that impose some kind of capital controls (restrictions), both for foreign direct and portfolio investment. Then, we estimated the Capital Control Index (CCI) in a conventional way attributing numbers for each aspect of the legislation that affects capital inflows and outflows. The idea was to state a plus one $(+1)$ for the episodes that favor the entrance of foreign capital and a negative one $(-1)$ for each restriction to capital inflow. This procedure was followed for each month and then we have the final score for the CC1, which takes into account the net effect favoring (positive number) or restricting (negative number) capital inflows. ${ }^{5}$

Another important variable of our model is a proxy for the uncovered interest parity differential (UIP) that we estimate using the following expression (in \% per year):

$$
\mathrm{UIP}=\left[\frac{(1+\mathrm{i})}{(1+\mathrm{e})(1+\mathrm{i} *)}-1\right] * 100
$$

where, in our specification, we used Selic rate as domestic interest rate (i), the Prime rate as the foreign interest rate $\left(\mathrm{i}^{*}\right)$ and the nominal exchange rate devaluation.

Our model also includes the Risk variable we used the average monthly J.P.

Morgan Emerging Markets Bond Index Plus (EMBI+) expressed in terms of

\footnotetext{
${ }^{5}$ The CC1 can be zero for example if in the same month we have one measure favoring and one measure restricting capital inflows.
} 
returns. Finally, we have the Net Capital Flows (KF) as the difference between the Net Portfolio Investment (PORTI) and the Net Foreign Direct Investment (FDI).

It is fair to use the VAR (Vector Autoregression) specification for forecasting systems of interrelated time series to analyze the dynamic impact of random disturbances on the system of variables. Once we have specified the VAR, we estimated the impulse response functions and variance decomposition. An impulse response function traces the effect of a one standard deviation shock to one of the innovations on current and future values of the endogenous variables. For example, consider the uncorrelated innovation vector $\left[\varepsilon_{1 t}, \varepsilon_{2 t}, \varepsilon_{3 t} \ldots \varepsilon_{n t}\right]$ from a VAR specification. The interpretation of the impulse response is straightforward. The $\varepsilon_{1 t}$ is the innovation for the first variable, $\varepsilon_{2 t}$ for the second one and so on. The impulse response functions for $\varepsilon_{2 t}$ measure the effect of a one standard deviation of the first variable shock on current and future first and second variables. In summary, impulse response functions trace the effect of a shock to an endogenous variable into the VAR 6 .

On the other hand, the variance decomposition provides a different method of depicting the system dynamics. It decomposes variation of an endogenous variable into the component shocks to the endogenous variables in the VAR. The variance decomposition gives information about the relative importance of each random innovation to the variables in the VAR. ${ }^{7}$

We first estimate a VAR including the following variables [UIP, Risk, CCI, KF], and than we decomposed net capital flows into net direct foreign investment (FDI) and net portfolio investment (PORTI) to run two more VARs including the same remaining three variables of our model. The information criteria (Schwarz and Akaike) were used for model selection in order to determine the lag length of the VAR, where the model (lag) was chosen based on the lower value of the information criteria.

The results of theses information criteria are shown in Tables $1 \mathrm{a}, 1 \mathrm{~b}$ and $1 \mathrm{c}$. As we can see, the reduction of the model from four lags to three lags is accepted, and so until one lag. In this case, we estimated the VAR (1) to analysis the impulse response functions and variance decomposition.

First of all, let us explain the results of the variance decomposition analysis. According to Tables $2 \mathrm{a}, 2 \mathrm{~b}$ and $2 \mathrm{c}$, almost seven percent $(7 \%)$ of the variance of the capital flows after ten months can be explained by reactions to shocks to capital controls, and only one percent $(1 \%)$ for the case of foreign direct investment and up to five percent $(5 \%)$ for portfolio investment. On the other hand, shocks to capital controls cannot be explained by reactions due to shocks in capital flows where these results does not depend on the composition of the capital. We can say that these results are different from the ones obtained by Cardoso and Goldfajn (1998, pp.29): "almost 20 percent of the variance of the capital controls can be explained by reactions to shocks to capital flows". Cardoso and Goldfajn use a

\footnotetext{
${ }^{6}$ We were worried about the hypothesis of Gaussian Errors when we estimate the VAR, where in some cases we introduce dummy variables as for the case of July 1994 and January 1999.

${ }^{7}$ For further details, see Hamilton' (1995) textbook, Stock and Watson (2001) or E-views 4.0 User Guide.
} 
different sample with monthly data from January of 1988 to December 1995 and this time period is quite different from the one we are examining in terms of external shocks, international liquidity and volatility of capital flows. It is fair to say that in a context of more volatility one can expect capital controls to work in a limited way when compared to times of quiescence.

The second interesting econometric finding is the fact that almost twenty percent $(20 \%)$ of the variance of the country risk can be explained by reactions to shocks to capital flows, where most of this variance comes from shocks in portfolio investment and not from foreign direct investment. More than eighteen percent $(18 \%)$ of the variance decomposition of the forecasted errors of the country risk after ten months can be explained by reactions to shocks in the interest rate differential, estimated as UIP , especially when we estimated the system with net portfolio investment $(17,78 \%)$. The Capital Controls Index (CCI) can explain up to $12,3 \%$ of reactions in the country risk, which means that when government authorities announces a new regulation on capital inflows or outflows, changes in the country risk can at most be affected by $12 \%$ due to this new regulation.

Finally, it is fair to say that almost $25 \%$ of the variance of the UIP can be explained by reactions to shocks to capital controls and net capital flows. But, when we consider the capital composition, we can see the role played by portfolio investment is much more than the one of foreign direct investment to explain this variance. In this case, it is relevant to consider the fact that the interest rate differential can be explained more by capital flows than it can explains capital flows, and consequently, the country risk in Brazil. This empirical finding is similar to the one suggested by Bresser-Pereira and Nakano (2002) and developed in the previous section. The Brazilian interest rate has been too high lately and this has affected the country risk. "This contagion can be explained based on the rationale of the creditors, that is, if Brazilian Authorities set the interest rate so high is because the country risk is high and high interest rate implies high amount of interest to be paid, improving the probability of default of Brazil”. (Bresser-Pereira and Nakano, 2002, pp.18).

Even though the variance decomposition allows one to understand the dynamic relationship between variables, we have to take into account the causalities established in these relationships. Granger (1969) develops a test in order to answer the question of whether $\mathrm{x}$ causes $\mathrm{y}$, i.e., to see how much of the current $\mathrm{y}$ can be explained by past values of $\mathrm{y}$ and then to see if by adding lagged values of $\mathrm{x}$ can improve the explanation. The variable $\mathrm{y}$ is said to be Granger-caused by $\mathrm{x}$ if $\mathrm{x}$ helps in the prediction of $y$, or equivalently if the coefficients on the lagged x's are statistically significant. Note that two-way causation is frequently the case; $x$ Granger causes $y$ and $y$ Granger causes $x$. It is important to note that the statement " $\mathrm{x}$ Granger causes y" does not imply that $\mathrm{y}$ is the effect or the result of $\mathrm{x}$. Granger

\footnotetext{
${ }^{8}$ It is important to highlight that the same econometric results for UIP were also found when we use the variable Brazilian interest rate, both in terms of intensity and direction. The Brazilian interest rate had moved abruptly when the foreign interest rate moved slowly and in _ of our sample data Brazil experienced a fixed but adjusted exchange rate regime.
} 
causality measures precedence and information content but does not by itself indicate causality in the more common use of the term. The null hypothesis is therefore that $\mathrm{x}$ does not Granger cause $\mathrm{y}$ in the first regression and that y does not Granger cause $x$ in the second regression. The test results are given by table $3 \mathrm{a}^{9}$.

Table 3a shows the results from the Granger Causality Test for the system with Net Capital Flows. Capital flows cause in Granger sense Risk in a system with four lags or more, but not with less lags, and UIP cause Risk only in a system with one lag, and independence of the lag length Risk does not Granger cause UIP. The other results keep on independence of the lag length ${ }^{10}$. In this case, there are two bi-causalities, one for country risk and capital flows and the other for the UIP and capital flows. In terms of capital composition, we can say that portfolio investment causes UIP and Risk, but the opposite is not true. Foreign direct investment does not cause Risk, but Risk causes foreign direct investment, while there is no (Granger) causality for UIP, FDI and CCI. In other words, foreign direct investment is different from portfolio investment because the second one causes Risk and UIP and the first one does not.

If we compare Granger causality analysis with the variance decomposition, it is fair to conclude that is not necessarily direct the relation between interest rate differential (UIP) and the Risk. It is possible the capital flows, mainly the portfolio flows cause in Granger sense UIP or is caused by UIP, because of the bivariate causality and, afterwards, it causes Risk. Of course, whether the fiscal debt improves joint with the foreign portfolio capital, the probability of the default can be increase and, consequently, this movement push to up the risk country. According to the Figures $1 \mathrm{a}$ and $1 \mathrm{~b}$ we can

Figura 1a: Federal Public Debt in Brazil 1994.7 - 2002.5 - Percent of GDP

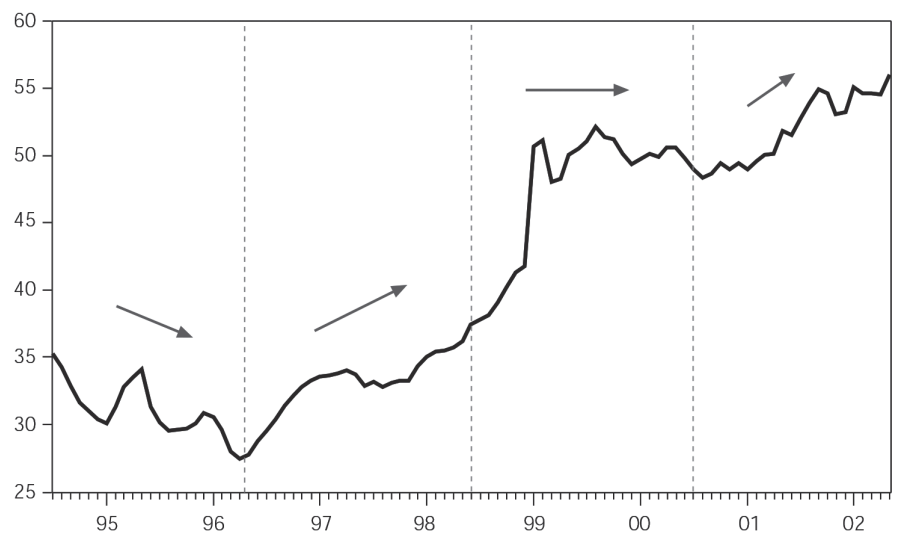

\footnotetext{
${ }^{9}$ We run the unit root tests (Augmented Dickey-Fuller) for each time series. The results have shown that Net Capital flows is stationary, but the foreign direct and the portfolio investment are both nonstationary in level, but stationary in first difference. The UIP is stationary, but the interest rate is nonstationary, and the Risk (EMBI+, from J.P. Morgan) and Public Debt in percent of GDP are both nonstationary in level, but stationary in first difference.

${ }^{10}$ In general it is better to use more rather than fewer lags, since the theory is couched in terms of the relevance of all past information. You should pick a lag length that corresponds to reasonable beliefs about the longest time over which one of the variables could help predict the other.
} 


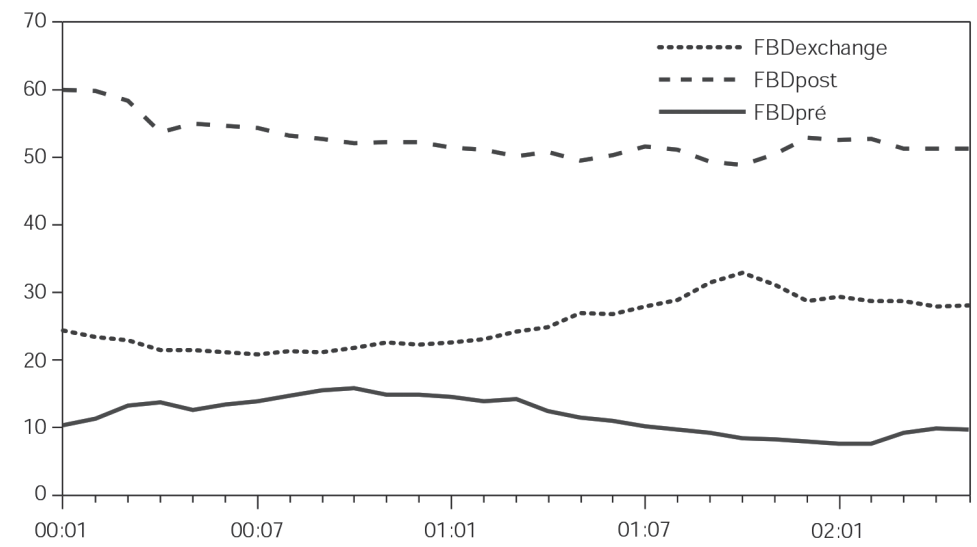

infer that: first, the Brazilian federal debt has improved very fast, mainly after exchange rate crisis in beginning of 1999; and, second, the correction of this amount of debt is concentrated in exchange rate and post-fixed interest rate. In a scenario of intensive devaluation of exchange rate with high interest rate, the probability of the default increases.

Considering the fact that the Brazilian net federal public debt has improved since 1996 we were not concerned to split the sample data in order to make inference about the probability of default, that is, if this probability becomes higher after the public debt overtake half of the GDP in 1999. Instead, we need to highlight that it is possible that the default hypothesis becomes easier to be accepted not only because of the improvement in the public debt, but also because it changes in average terms in a fast way, from $35 \%$ of the GDP to $55 \%$ of GDP in a short period of time. Figure 2 illustrates this when the horizontal public federal debt curve (Div) divides the probability of the default in two moments. The first one is less exponential and corresponds to a situation where monetary authorities are able to reduce interest rate and the probability of default goes down, and the second moment is plotted after this horizontal curve, when a high interest rate is interpreted as a signal of fragility and there is a tendency to move towards point $\mathrm{B}$ instead of $\mathrm{C}^{11}$.

We can observe this situation in an illustrative way represented by figure 2 (Brazilian Default Curve), which is plotted to express the relationship between the probability of default and the interest rate conditional to federal public debt as a percentage of GDP (Div). The Probability of the Default can be expressed as follow:

Prob $($ default $)=f(i \mid$ Div $)=Z$

where, $Z \rightarrow 1$, if Div $>50 \%$ GDP, and $Z \rightarrow 0$, if Div $<50 \%$ GDP. In figure

2 , point $\mathrm{C}$ represents the critical situation when an increase in the interest rate

\footnotetext{
${ }^{11}$ Point A represents the situation where both the country risk and the interest rate are at low level.
} 
is followed by a faster increase in the Prob (default). When the interest rate is between the critical level $\left(i_{c}\right)$ and default level $\left(i_{e}\right)$ there is a high propensity to believe in default even if the monetary authorities reduce the interest rate. In this situation, capital controls hardly work well, either to improve the quality of capital inflows, or to avoid the bloodshed of capital outflows. In this special case, a simple equation can express the variable country risk as a function of the probability of default:

$$
\text { Risk }=\operatorname{Div}+\left(e^{D i v}\right) \cdot\left(i_{n}-i_{c}\right)-\gamma \text { for } \mathrm{n}=0 \ldots . \mathrm{T}
$$

where the Risk increases exponentially with the federal public debt once interest rate overtakes a critical level, that cross in critical level of the probability of the default $(\mathrm{Zc})$. We can say that $\gamma$ represents the institutional skills to manage the public debt between monetary authorities and creditors and how credible it is this interaction.

Figure 2: Brazilian Default Curve

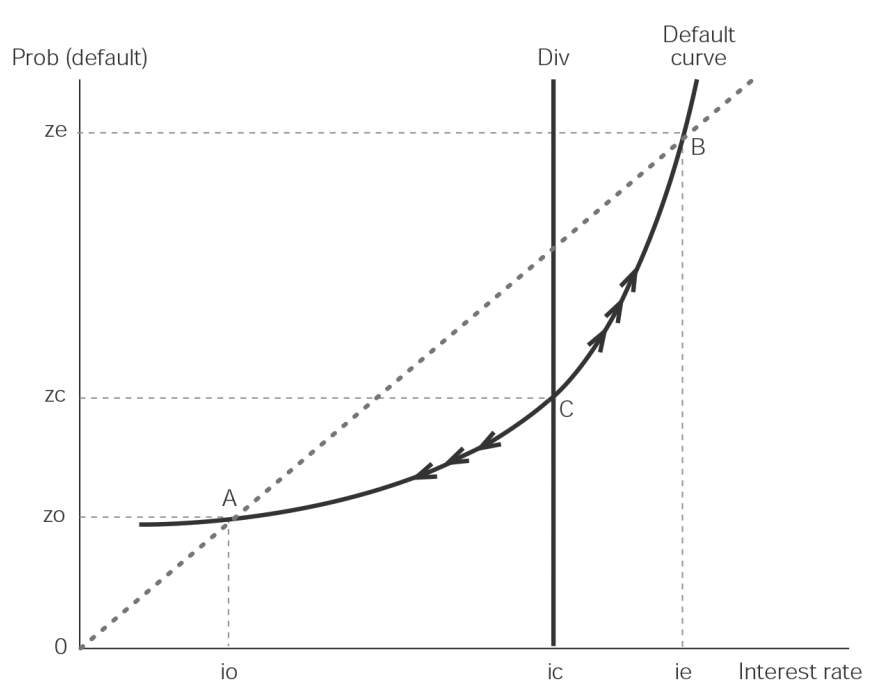

Examining figure 3, we can check the above argument when we observe that the country risk behavior follows the same path of the interest rate. In our framework, there is a critical level for the federal public debt as a percentage of the GDP and after this level, the country risk increases with the interest rate, and this movement does not depend only on fiscal policy issues, mainly if the interest rate reaches the level $\mathrm{i}_{\mathrm{e}}$ and the economy is at point $\mathrm{B}$. We are assuming that the public debt is basically represented by short-term debt and the amount of payments depends on both post-fixed interest rate and the exchange rate in a floating exchange rate regime.

The empirical analysis provided by the impulse response functions is based on the plots from figures $4 \mathrm{c}, 4 \mathrm{~d}$ and $4 \mathrm{e}$. One of the first insights one can draw after examining these figures is the evidence there is a response of capital controls to 
capital flows, both for portfolio and direct investment, in the same direction, but the effect does not last long. On the other hand, there is a clear evidence of a negative response of capital flows to capital controls, with stronger effect for portfolio capital when compared to foreign direct investment, where the effect lasts for more than three months. This kind of empirical finding is in fine tuning with the literature suggesting that capital controls have no significant long-term effect and that capital controls react to changes in capital flows (Cardoso and Goldfajn, 1998), or in terms of differential effect found for portfolio capital (Montiel and Reinhart, 1999).

Figure 3: Cross-plot Brazil-Risk versus Interest Rate

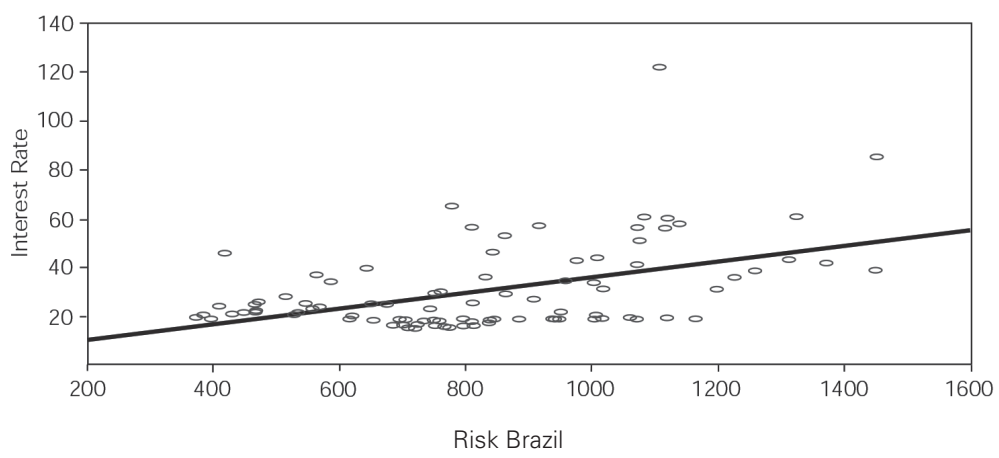

The response of the uncovered interest parity (UIP) to the country risk indicates the presence of what we can call the "default fear" hypothesis. In the same direction, there is a significant response of the UIP to capital movements, and this result does not depend on the foreign capital composition. Another interesting result is the negative response produced by capital controls on capital flows, and the response of the UIP to the CCI. In this case, when the Monetary Authorities impose some restrictions to capital inflows or outflows, they are forced to keep the interest rate at a high level.

\section{CONCLUDING REMARKS}

The empirical framework followed by the paper has provided some interesting insights. First, capital controls have played a more important role in Brazil in the period prior to our analysis as suggested by Cardoso and Goldfjan (1998), which can be understood when we consider the fact that more recently Brazil has faced a period of liquidity crisis and a more volatile capital account. Furthermore, we can say that capital controls have no significant long-term effect on capital flows and that capital controls react to changes in capital flows. Whether capital controls play an important role for capital flows it must be considered in a separate way since the effects when considering portfolio capital are much more significant when compared to foreign direct investment. 
Second, our empirical results suggest that the interest rate differential is endogenous to the country risk. In other words, even though investors take into account the forward interest rate and the expected devaluation of the exchange rate when comparing them with the foreign interest rate to address their expected returns, they attribute a higher probability of default when the Monetary Authorities follow a policy based on a high interest rate level and the extra burden due to future interest payments. Our research allowed us consider too the important role of the profile and the public debt in percent of the GDP, as much as the rate of the growth of the debt.

Finally, we can say that the Brazilian Default Curve during the recent floating experience is likely to be expressed in the neighborhood of the critical level, especially once we consider the public debt profile and the amount of interest to be paid in a short period of time. After all, it seems to exist a channel of transmission between high interest rates and a higher probability of default.

\section{APPENDIX}

Table 1a. Model S election for VAR [UIP, Risk, CCI, KF]

\begin{tabular}{cccc}
\hline System / Selection Criteria & Log Likelihood & $\begin{array}{c}\text { Akaike } \\
\text { Information Criteria }\end{array}$ & $\begin{array}{c}\text { SCHWARZ } \\
\text { CRITERIA }\end{array}$ \\
\hline System 04 lags & -1282.777 & -1280.748 & -1278.510 \\
System 03 lags & -1320.075 & -1318546 & -1316.849 \\
System 02 lags & -1352.238 & -1351.194 & -1350.029 \\
System 01 lags & -1402.238 & -1401.667 & -1401.025 \\
\hline
\end{tabular}

Table 1b. Model S election for VAR [UIP, Risk, CCI, FDI]

\begin{tabular}{cccc}
\hline System / Selection Criteria & Log Likelihood & $\begin{array}{c}\text { Akaike } \\
\text { Information Criteria }\end{array}$ & $\begin{array}{c}\text { SCHWARZ } \\
\text { CRITERIA }\end{array}$ \\
\hline System 04 lags & -1482.058 & -1480.399 & -1478.403 \\
System 03 lags & -1527.515 & -1526.262 & -1524.747 \\
System 02 lags & -1564.012 & -1563.155 & -1562.113 \\
System 01 lags & -1616.296 & -1615.826 & -1615.251 \\
\hline
\end{tabular}

Table 1c. Model S election for VAR [UIP, Risk, CCI, PORTI]

\begin{tabular}{cccc}
\hline System / Selection Criteria & Log Likelihood & $\begin{array}{c}\text { Akaike } \\
\text { Information Criteria }\end{array}$ & $\begin{array}{c}\text { SCHWARZ } \\
\text { CRITERIA }\end{array}$ \\
\hline System 04 lags & -1534.830 & -1533.172 & -1531.176 \\
System 03 lags & -1575.389 & -1574.136 & -1572.620 \\
System 02 lags & -1606.801 & -1605.944 & -1604.902 \\
System 01 lags & -1657.260 & -1656.790 & -1656.215 \\
\hline
\end{tabular}


Table 2a Variance Decomposition using Net Capital Flows

\begin{tabular}{cccccc}
\hline Period (Months) & & & & & \\
\hline Variance Decomposition of KF: & S.E. & KF & CCI & UIP & DRISK \\
1 & 2486.914 & 100.0000 & 0.000000 & 0.000000 & 0.000000 \\
2 & 2875.653 & 93.56409 & 4.344365 & 1.704445 & 0.387102 \\
5 & 3041.695 & 91.20052 & 6.758596 & 1.689695 & 0.351184 \\
10 & 3047.353 & 91.12613 & 6.826615 & 1.697283 & 0.349968 \\
\hline Variance Decomposition of CCI: & & & & & \\
1 & 1.491152 & 0.330260 & 99.66974 & 0.000000 & 0.000000 \\
2 & 1.510615 & 2.089717 & 97.36137 & 0.208587 & 0.340325 \\
5 & 1.517252 & 2.412433 & 96.94222 & 0.302945 & 0.342400 \\
10 & 1.517375 & 2.421916 & 96.93245 & 0.303266 & 0.342368 \\
\hline Variance Decomposition of UIP: & & & & & \\
1 & 5.845589 & 8.875574 & 2.720428 & 88.40400 & 0.000000 \\
2 & 6.532213 & 7.137749 & 15.98590 & 75.30213 & 1.574222 \\
5 & 6.622183 & 7.344396 & 16.03576 & 75.06734 & 1.552496 \\
10 & 6.622604 & 7.344507 & 16.04202 & 75.06087 & 1.552599 \\
\hline 1 & & & & & \\
2 & 109.4470 & 23.90616 & 0.244089 & 16.39424 & 59.45552 \\
5 & 119.9935 & 20.00213 & 11.48479 & 18.33295 & 50.18013 \\
\hline Variance Decomposition of DRIS K: & 121.0178 & 19.78058 & 12.31271 & 18.17505 & 49.73166 \\
& 121.0236 & 19.78426 & 12.31402 & 18.17472 & 49.72700 \\
\hline & & & & &
\end{tabular}

Table 2b. Variance Decomposition using Foreign Direct Investment (FDI)

\begin{tabular}{cccccc}
\hline Period (Months) & & & & & \\
\hline Variance Decomposition of CCI: & S.E. & CCI & DRISK & UIP & FDI \\
1 & 1.371925 & 100.0000 & 0.000000 & 0.000000 & 0.000000 \\
2 & 1.394086 & 97.03636 & 2.070231 & 0.009420 & 0.883993 \\
5 & 1.398175 & 96.80686 & 2.076644 & 0.039045 & 1.077447 \\
10 & 1.398221 & 96.80074 & 2.077047 & 0.039218 & 1.082996 \\
\hline Variance Decomposition of DRIS K & & & & & \\
1 & 104.6136 & 0.083182 & 99.91682 & 0.000000 & 0.000000 \\
2 & 113.2494 & 9.604720 & 87.35736 & 2.263372 & 0.774550 \\
5 & 114.3293 & 10.41902 & 86.25761 & 2.376233 & 0.947145 \\
10 & 114.3342 & 10.41913 & 86.25373 & 2.377197 & 0.949937 \\
\hline 1 & 5.353702 & 2.290144 & 24.74627 & 72.96359 & 0.000000 \\
2 & 5.950428 & 14.71795 & 20.05390 & 64.54164 & 0.686520 \\
5 & 6.024768 & 14.85826 & 20.36092 & 64.07963 & 0.701186 \\
10 & 6.024978 & 14.86201 & 20.35980 & 64.07597 & 0.702213 \\
\hline
\end{tabular}




\begin{tabular}{cccccc}
\hline Variance Decomposition of FDI: & \multicolumn{1}{c}{} \\
\hline 1 & 970.8924 & 0.973858 & 0.027785 & 3.870708 & 95.12765 \\
2 & 1093.234 & 0.770875 & 1.566239 & 3.201191 & 94.46169 \\
5 & 1141.629 & 0.833416 & 2.451877 & 3.201777 & 93.51293 \\
10 & 1142.871 & 0.845531 & 2.478534 & 3.196557 & 93.47938 \\
\hline
\end{tabular}

Table 2c. Variance Decomposition using Portfolio Investment (PORTI)

\begin{tabular}{|c|c|c|c|c|c|}
\hline Period (Months) & & & & & \\
\hline Variance Decomposition of PORTI: & S.E. & PORTI & UIP & $\mathrm{CCl}$ & DRISK \\
\hline 1 & 1797.838 & 100.0000 & 0.000000 & 0.000000 & 0.000000 \\
\hline 2 & 2010.536 & 93.48954 & 3.236709 & 2.480211 & 0.793536 \\
\hline 5 & 2066.092 & 90.36404 & 3.785545 & 4.565889 & 1.284526 \\
\hline 10 & 2066.343 & 90.34646 & 3.790135 & 4.575727 & 1.287678 \\
\hline \multicolumn{6}{|l|}{ Variance Decomposition of UIP: } \\
\hline 1 & 5.373563 & 17.25067 & 82.74933 & 0.000000 & 0.000000 \\
\hline 2 & 5.945413 & 14.10880 & 69.85324 & 14.92916 & 1.108798 \\
\hline 5 & 6.026750 & 14.29068 & 69.34404 & 15.23114 & 1.134141 \\
\hline 10 & 6.026951 & 14.28988 & 69.33989 & 15.23586 & 1.134361 \\
\hline \multicolumn{6}{|l|}{ Variance Decomposition of $\mathrm{CCl}$ : } \\
\hline 1 & 1.377455 & 0.144276 & 2.677224 & 97.17850 & 0.000000 \\
\hline 2 & 1.394527 & 1.496223 & 2.821068 & 94.96341 & 0.719299 \\
\hline 5 & 1.399162 & 1.601588 & 3.023305 & 94.60261 & 0.772499 \\
\hline 10 & 1.399176 & 1.601659 & 3.023406 & 94.60220 & 0.772734 \\
\hline \multicolumn{6}{|l|}{ Variance Decomposition of DRIS K: } \\
\hline 1 & 104.2534 & 21.28331 & 13.30963 & 0.027826 & 65.37923 \\
\hline 2 & 113.4057 & 17.99031 & 18.42355 & 7.478948 & 56.10719 \\
\hline 5 & 114.2659 & 17.78443 & 18.23432 & 8.506943 & 55.47431 \\
\hline 10 & 114.2668 & 17.78423 & 18.23456 & 8.507767 & 55.47344 \\
\hline
\end{tabular}


Table 3a. Pairwise Granger Causality Tests

\begin{tabular}{|c|c|c|c|}
\hline Null Hypothesis: & Obs & F-Statistic & Probability \\
\hline DRISK does not Granger Cause KF & 70 & 0.01018 & 0.91995 \\
\hline KF does not Granger Cause DRISK & & 0.93804 & 0.33627 \\
\hline UIP does not Granger Cause KF & 70 & 2.72355 & 0.10356 \\
\hline KF does not Granger Cause UIP & & 0.48689 & 0.48773 \\
\hline $\mathrm{CCl}$ does not Granger Cause KF & 70 & 3.82524 & 0.05466 \\
\hline KF does not Granger Cause CCl & & 1.77021 & 0.18787 \\
\hline UIP does not Granger Cause DRISK & 91 & 5.94507 & 0.01677 \\
\hline DRISK does not Granger Cause UIP & & 0.25692 & 0.61351 \\
\hline $\mathrm{CCl}$ does not Granger Cause DRISK & 93 & 7.00144 & 0.00961 \\
\hline DRISK does not Granger Cause $\mathrm{CCl}$ & & 4.45462 & 0.03758 \\
\hline $\mathrm{CCl}$ does not Granger Cause UIP & 91 & 7.69545 & 0.00676 \\
\hline UIP does not Granger Cause CCl & & 0.01139 & 0.91524 \\
\hline UIP does not Granger Cause PORTI & 81 & 1.22777 & 0.30538 \\
\hline PORTI does not Granger Cause UIP & & 3.06669 & 0.01466 \\
\hline DRISK does not Granger Cause PORTI & 83 & 1.64404 & 0.15939 \\
\hline PORTI does not Granger Cause DRISK & & 4.86642 & 0.00069 \\
\hline $\mathrm{CCl}$ does not Granger Cause PORTI & 83 & 1.22279 & 0.30733 \\
\hline PORTI does not Granger Cause CCl & & 0.37600 & 0.86359 \\
\hline UIP does not Granger Cause FDI & 81 & 1.05095 & 0.39503 \\
\hline FDI does not Granger Cause UIP & & 0.54693 & 0.74008 \\
\hline DRISK does not Granger Cause FDI & 83 & 2.63039 & 0.03059 \\
\hline FDI does not Granger Cause DRISK & & 1.86798 & 0.11061 \\
\hline $\mathrm{CCl}$ does not Granger Cause FDI & 83 & 0.07601 & 0.99568 \\
\hline FDI does not Granger Cause CCl & & 1.82544 & 0.11863 \\
\hline All variables in first difference & & & \\
\hline
\end{tabular}




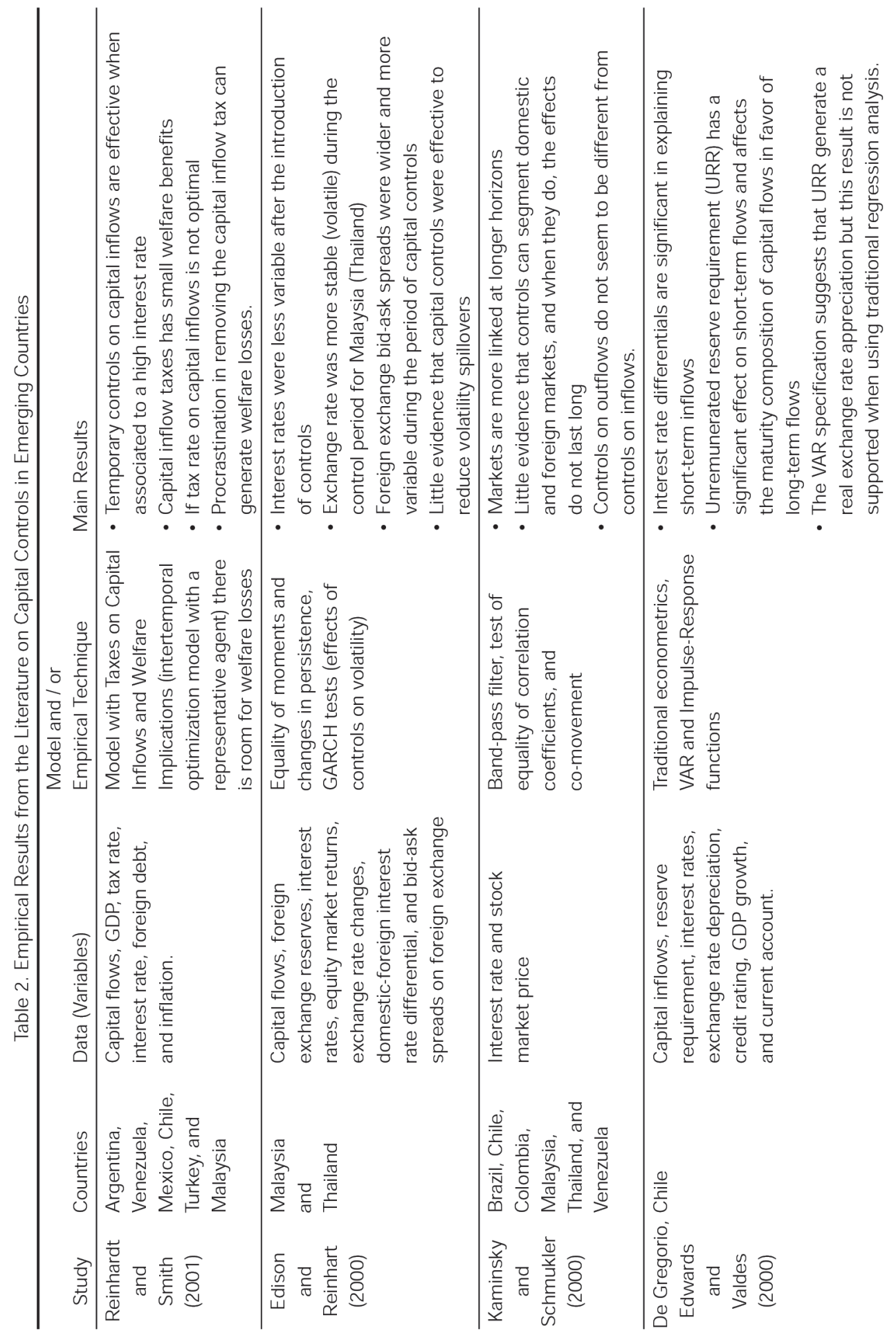




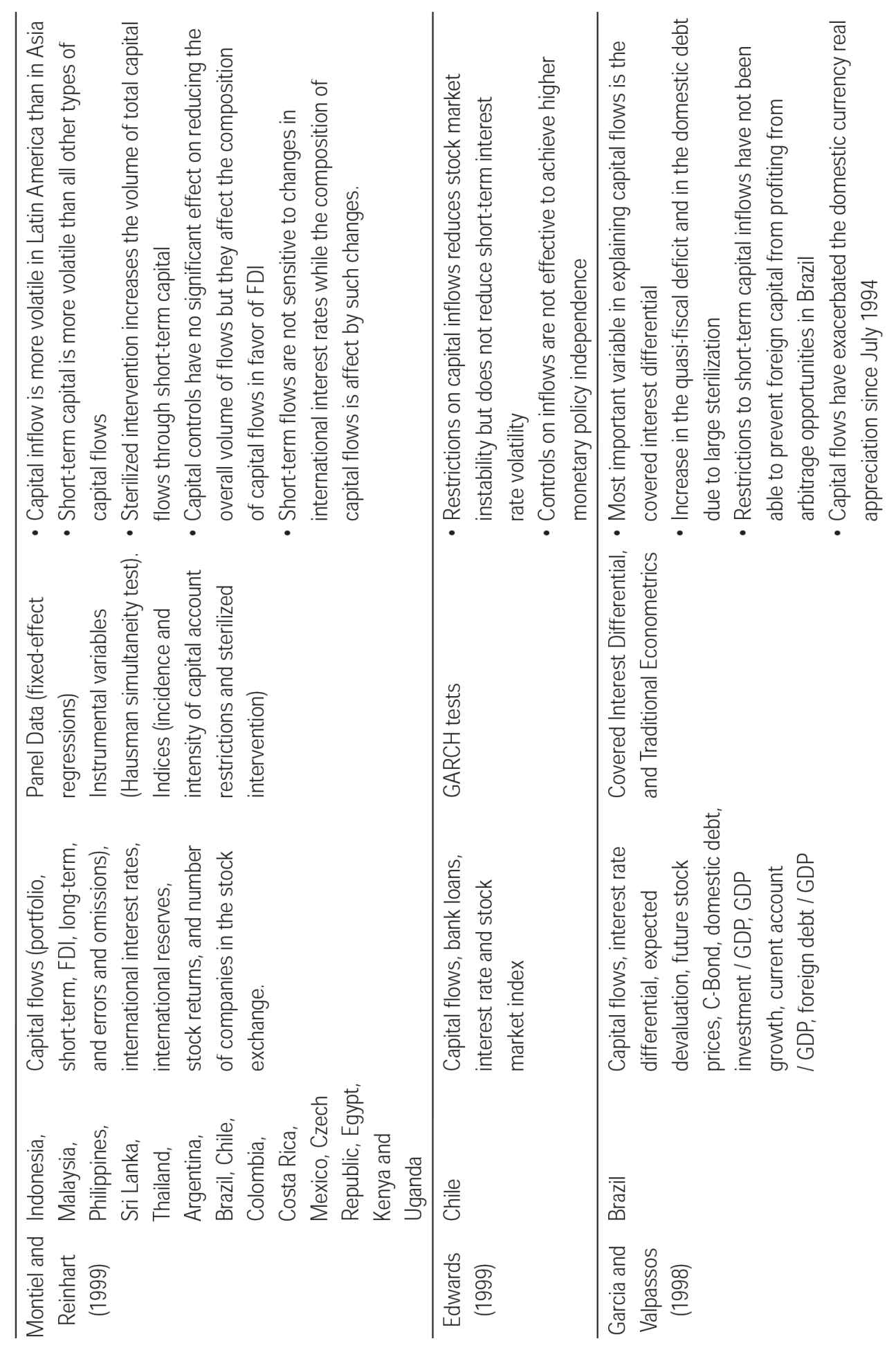




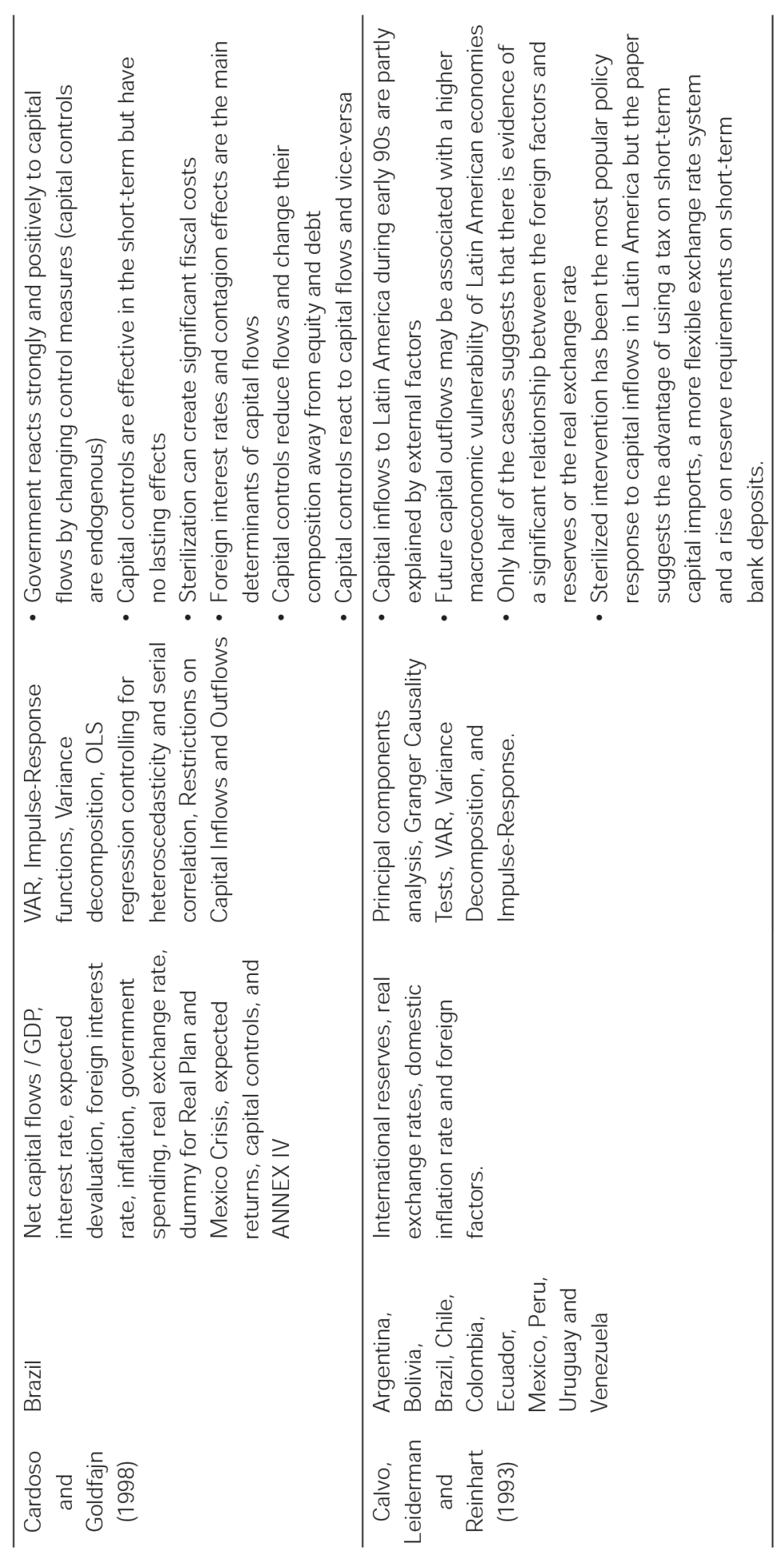


Figure 1c. Impulse Response Functions - Net Capital Flows

Response to One S.D. Innovations \pm 2 S.E.

Response of $\mathrm{CCl}$ to $\mathrm{KF}$

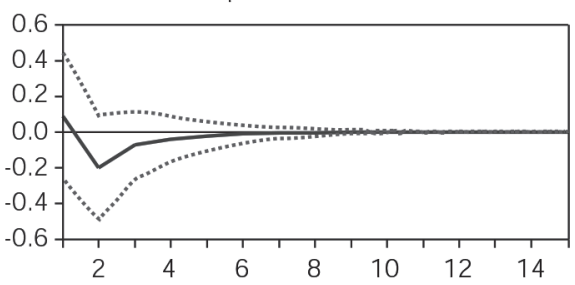

Response of UIP to KF

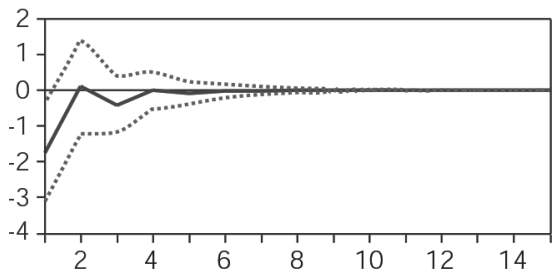

Response of DRISK to KF

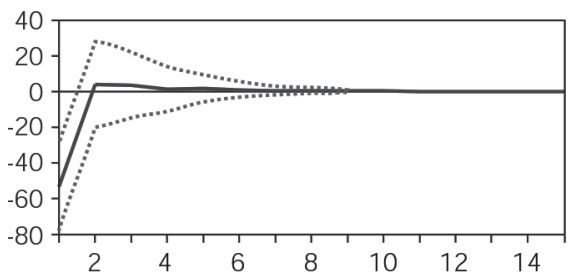

Response to One S.D. Innovations \pm 2 S.E. Response of KF to DRISK

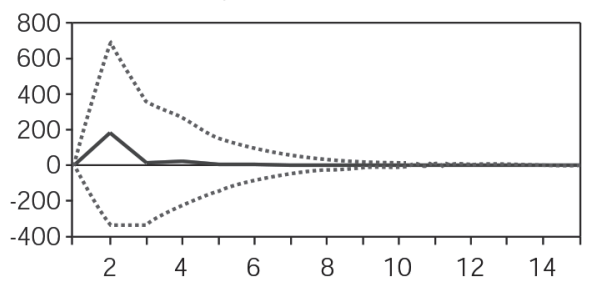

Response of $\mathrm{CCl}$ to DRISK

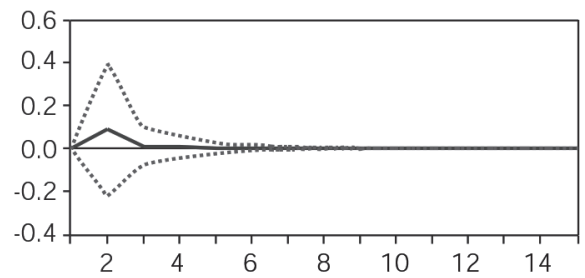

Response of UIP to DRISK

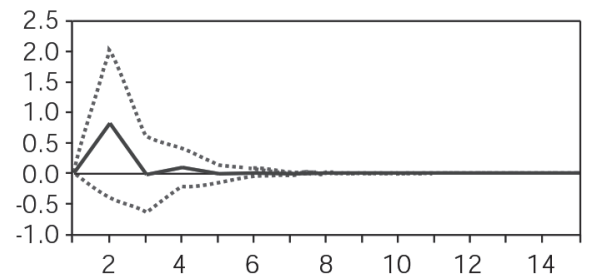


Figure 1c. Impulse Response Functions - Net Capital Flows (cont.)

Response to One S.D. Innovations \pm 2 S.E.

Response of $\mathrm{KF}$ to $\mathrm{CCl}$

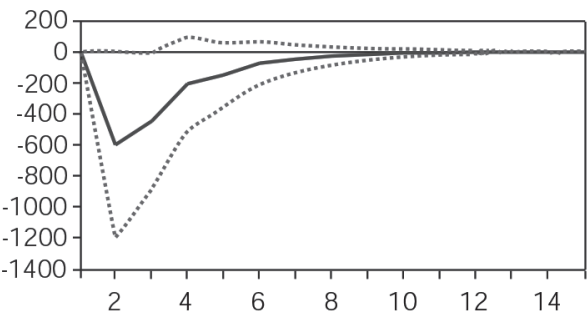

Response of UIP to $\mathrm{CCl}$

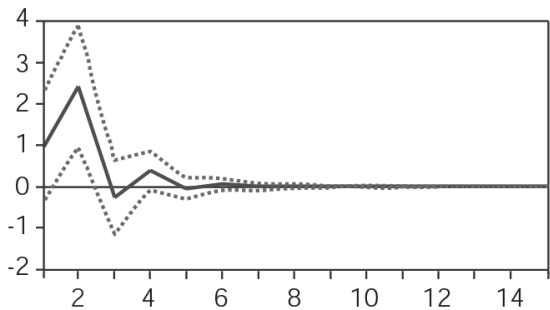

Response of DRISK to $\mathrm{CCl}$

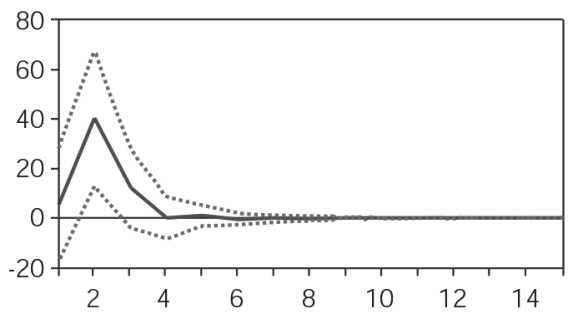

Response to One S.D. Innovations \pm 2 S.E. Response of KF to UIP

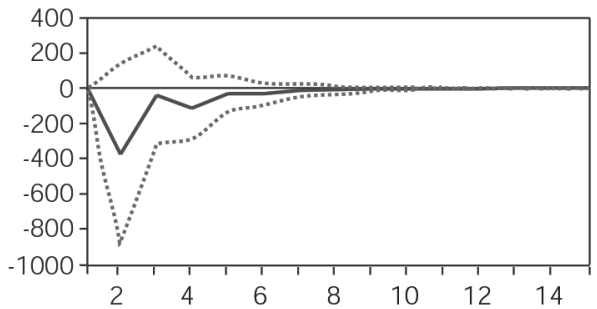

Response of CCI to UIP

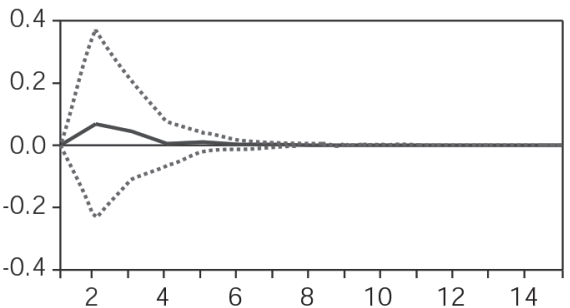

Response of DRISK to UIP

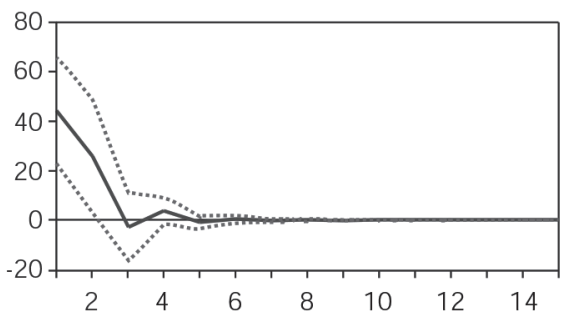


Figure 1d. Impulse Response Functions - Foreign Direct Investment

Response to One S.D. Innovations \pm 2 S.E.

Response of $\mathrm{CCl}$ to FDI

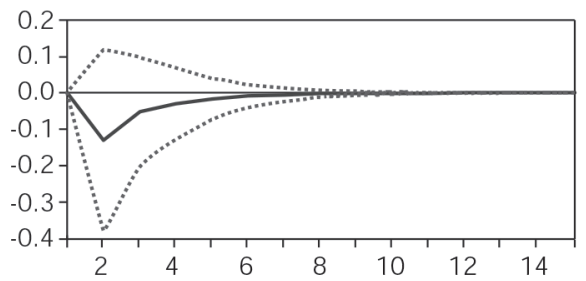

Response of DRISK to FDI

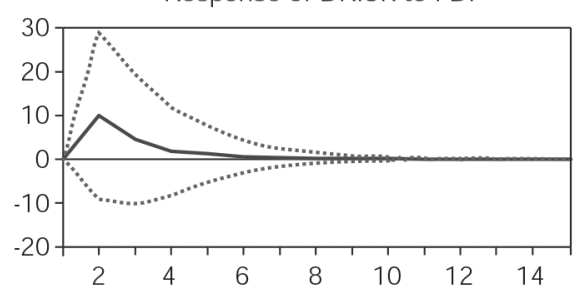

Response of UIP to FDI

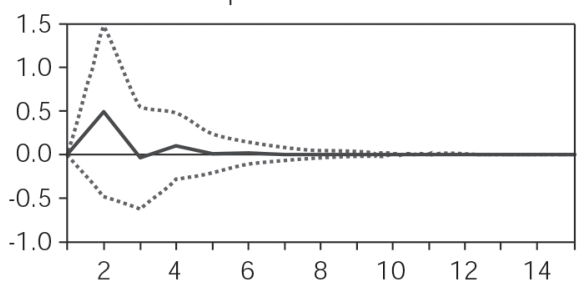

Response to One S.D. Innovations \pm 2 S.E. Response of KF to UIP

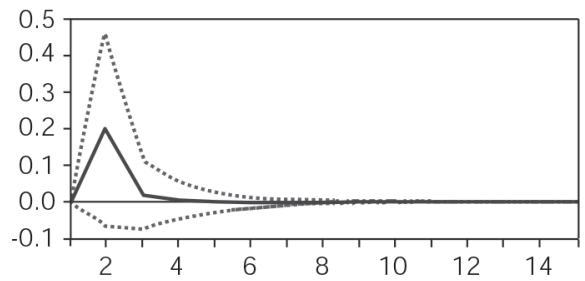

Response of UIP to DRISK

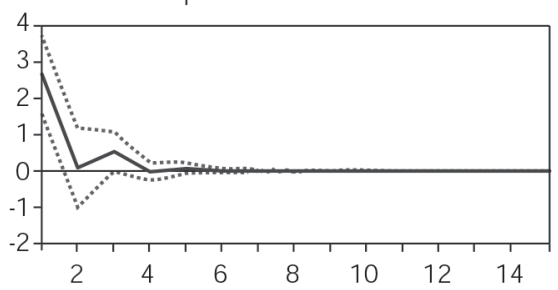

Response of FDI to DRISK

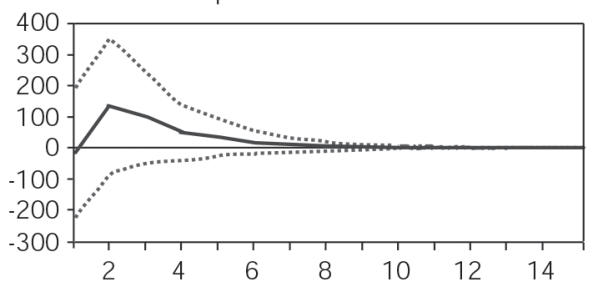


Figure 1d. Impulse Response Functions - Foreign Direct Investment (cont.)

Response to One S.D. Innovations \pm 2 S.E.

Response of UIP to CCI

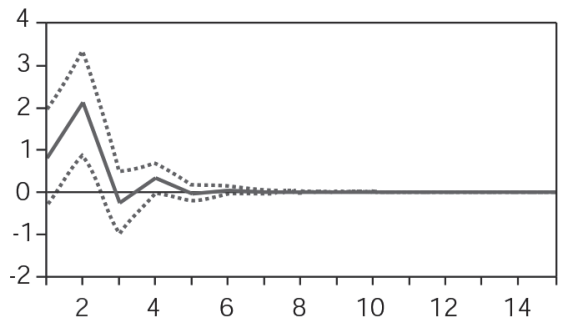

Response of DRISK to $\mathrm{CCl}$

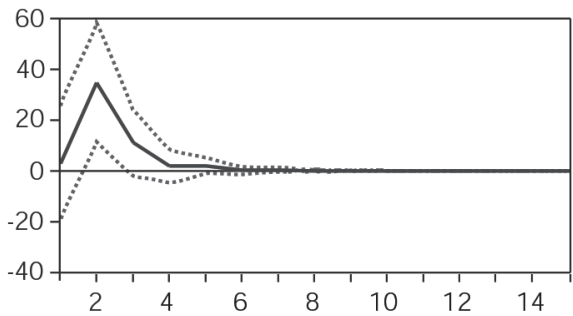

Response of FDI to $\mathrm{CCl}$

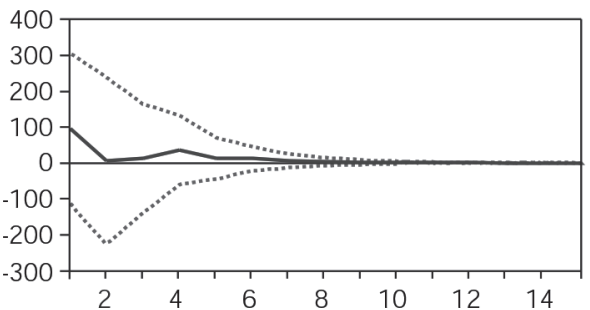

Response to One S.D. Innovations \pm 2 S.E. Response of CCI to UIP

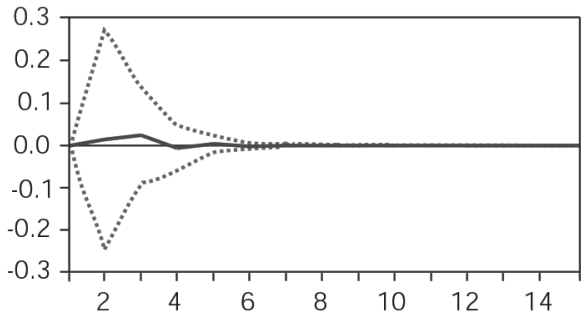

Response of DRISK to UIP

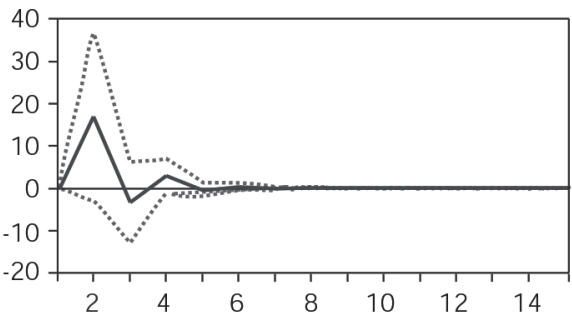

Response of FDI to UIP

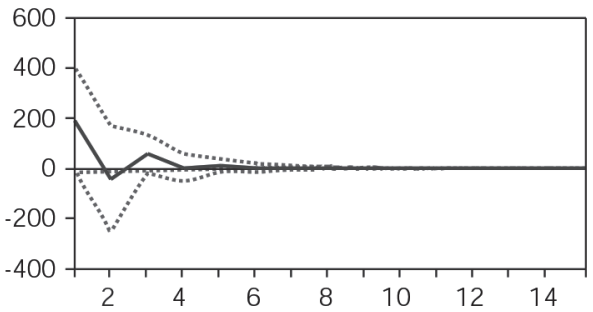


Figure 1e. Impulse Response Functions - Portfolio Investment

Response to One S.D. Innovations \pm 2 S.E.

Response of UIP to PORTI

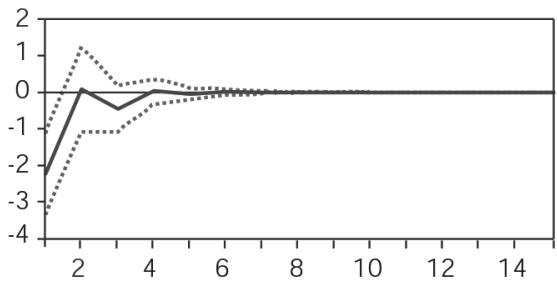

Response of CCI to PORTI

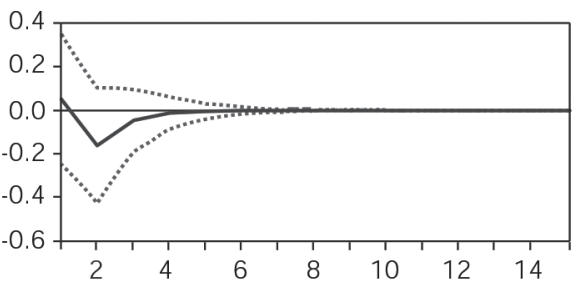

Response of DRISK to PORTI

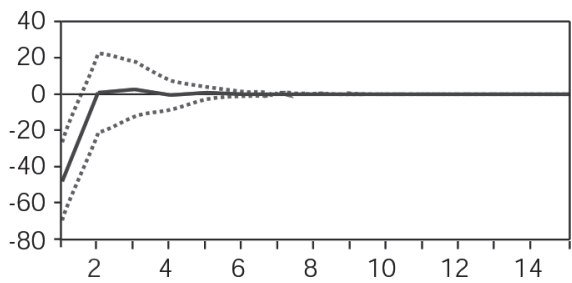

Response to One S.D. Innovations \pm 2 S.E.

Response of PORTI to DRISK

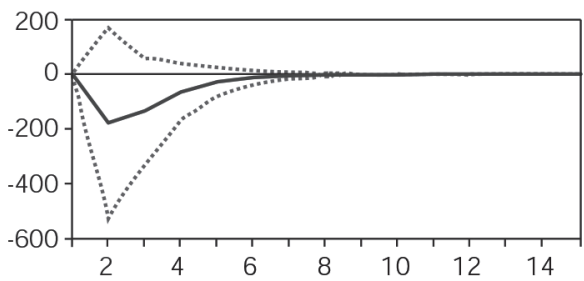

Response of UIP to DRISK

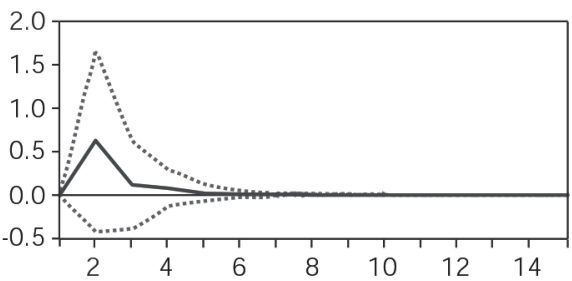

Response of $\mathrm{CCl}$ to DRISK

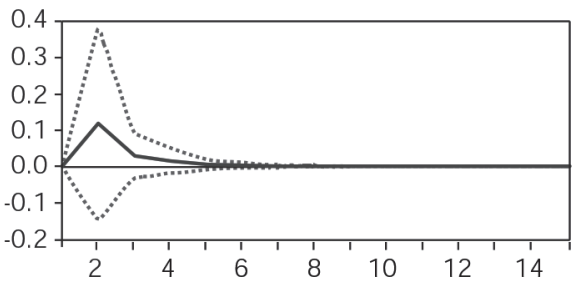


Figure 1e. Impulse Response Functions - Portfolio Investment (cont.)

Response to One S.D. Innovations \pm 2 S.E.

Response of PORTI to $\mathrm{CCl}$

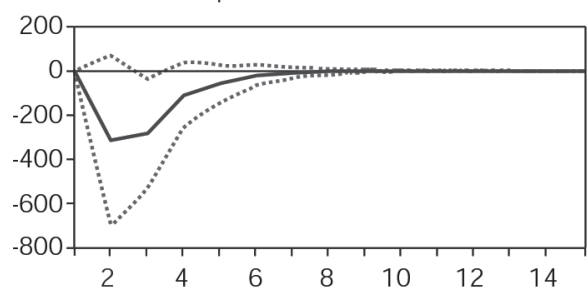

Response of UIP to $\mathrm{CCl}$

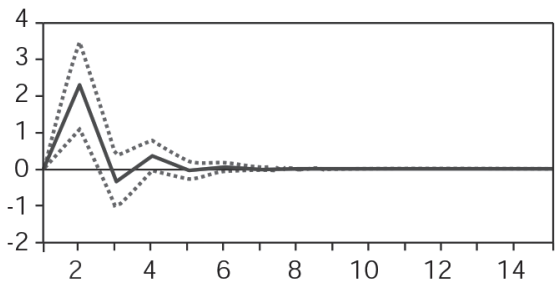

Response of DRISK to CCI

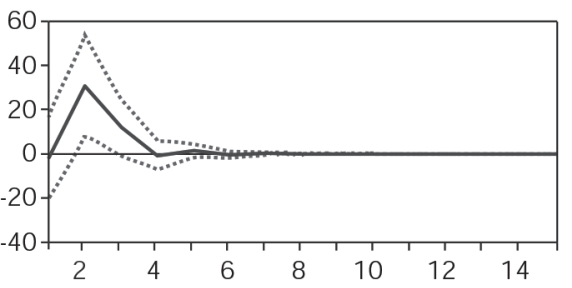

Response to One S.D. Innovations \pm 2 S.E. Response of PORTI to UIP

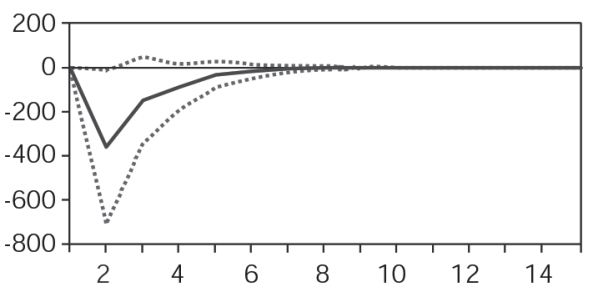

Response of CCl to UIP

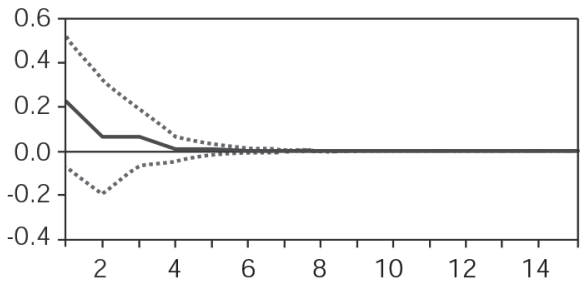

Response of DRISK to UIP

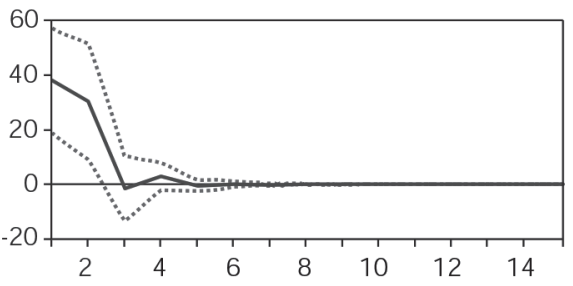




\section{REFERENCES}

ALESINA, A ; V. GRILLI and G.M. MILESI (1994). "The Political Economy of Capital Controls”. In: L. Leiderman and A Razin, (eds) Capital Mobility: the Impact on Consumption, Investment and Growth. Cambridge University Press: 289-321.

BRESSER-PEREIRA, L. C. and NAKANO, Y. (2002). "Uma estratégia de desenvolvimento com estabilidade”. São Paulo, janeiro 2002. (mimeo).

CALVO, Leiderman and REINHART, (1993). "Capital inflows and real exchange rate appreciation in Latin America”. IMF Staff Papers. 40(1). Washington, D.C. IMF, March 1993.

CARDOSO, E. and GOLDFAJN, I. (1998). "Capital flows to Brazil: the endogeneity of the capital controls”. IMF Working Paper 115. Washington, D.C: IMF, September 1998.

DE GREGORIO, J., EDWARDS, S. and VALDES, R. O. (2000). "Controls on capital inflows: do they work?” NBER Working Paper Series 7645. Cambridge, USA, April 2000.

EDISON, H. and REINHART, C. (2000). "Stopping Hot Money". NBER Working Paper Series, November 1999.

EDWARDS, S. (1999). “How Effective are Capital Controls?” NBER Working Paper Series 7413. Cambridge, USA, November, 1999.

EDWARDS, S. (1998). "Capital inflows into Latin America: a stop-go story”. NBER Working Paper Series 6441. Cambridge, USA, March 1998.

E-VIEWS 4.0. User Guide.

GARCIA and VALPASSOS (1998). "Capital flows, capital controls and currency crisis: the case of the Brazil in the nineties”. Rio de Janeiro, Texto para Discussão PUC-Rio No. 389, novembro de 1998.

GRANGER, C. W. (1969). “Investigating Causal Relations by Econometric Models and Cross-Spectral Methods”. Econometrica, 37, 424-438.

HAMILTON, J. (1995). Time Series Analysis. Princeton: University Press.

KAMINSKY, G. and SCHMUKLER, S. (2000). Short and long run integration. Do Capital controls matter? Washington, D.C. The World Bank, 2000. (mimeo)

KRUGMAN, P. (1998) “Saving Asia: It's Time to Get Radical”. Fortune, September 7, p. 74-80.

MONTIEL, P. and REINHART, C. (1999). "Do capital controls and macroeconomic policies influence the volume and composition of capital flows? Evidence from the 1990s.” NBER Working Paper Series, March 1997.

PASTORE, A. C. (2002). The Bresser-Nakano economic policy proposals. São Paulo. AC Pastore and Associados, Informe Especial 05/06/2002.

REINHARDT, C. and SMITH, R. T. (2001) “Temporary Controls on Capital Inflows". NBER Working Paper Series 8422, August, 2001.

RODRIK (1998) "Who Needs Capital-Account Convertibility? Should the IMF Pursue Capital-Account Convertibility". Essays in International Finance 207, Princeton, USA.

STOCK, J. H. and WATSON, M. W. (2001). "Vector Autoregessions". Journal of Economic Perspectives, Symposium on Econometric Tools. March 2001. (forthcoming)

TOBIN, J. (1978) “A Proposal for International Monetary Reform”. Eastern Economic Journal, p.154159. 